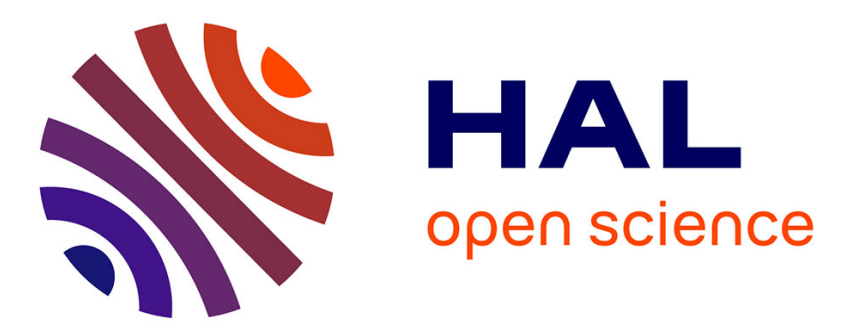

\title{
Biological relevance of double lipoxygenase products of polyunsaturated fatty acids, especially within blood vessels and brain
}

\author{
Michel Guichardant, Evelyne Véricel, Michel Lagarde
}

\section{- To cite this version:}

Michel Guichardant, Evelyne Véricel, Michel Lagarde. Biological relevance of double lipoxygenase products of polyunsaturated fatty acids, especially within blood vessels and brain. Biochimie, 2019, 159, pp.55-58. 10.1016/j.biochi.2018.08.009 . inserm-01872365

\section{HAL Id: inserm-01872365 https://www.hal.inserm.fr/inserm-01872365}

Submitted on 12 Sep 2018

HAL is a multi-disciplinary open access archive for the deposit and dissemination of scientific research documents, whether they are published or not. The documents may come from teaching and research institutions in France or abroad, or from public or private research centers.
L'archive ouverte pluridisciplinaire HAL, est destinée au dépôt et à la diffusion de documents scientifiques de niveau recherche, publiés ou non, émanant des établissements d'enseignement et de recherche français ou étrangers, des laboratoires publics ou privés. 


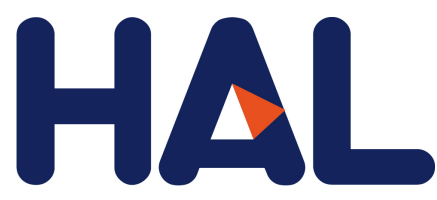

archives-ouvertes

\section{Biological relevance of double lipoxygenase products of polyunsaturated fatty acids, especially within blood vessels and brain}

Michel Guichardant, Evelyne Véricel, Michel Lagarde

\section{- To cite this version:}

Michel Guichardant, Evelyne Véricel, Michel Lagarde. Biological relevance of double lipoxygenase products of polyunsaturated fatty acids, especially within blood vessels and brain. Biochimie, Elsevier, 2018, <10.1016/j.biochi.2018.08.009>. <inserm-01872365>

\section{HAL Id: inserm-01872365 http://www.hal.inserm.fr/inserm-01872365}

Submitted on 12 Sep 2018

HAL is a multi-disciplinary open access archive for the deposit and dissemination of scientific research documents, whether they are published or not. The documents may come from teaching and research institutions in France or abroad, or from public or private research centers.
L'archive ouverte pluridisciplinaire HAL, est destinée au dépôt et à la diffusion de documents scientifiques de niveau recherche, publiés ou non, émanant des établissements d'enseignement et de recherche français ou étrangers, des laboratoires publics ou privés. 


\title{
Biological relevance of double lipoxygenase products of polyunsaturated fatty acids, especially within blood vessels and brain
}

\author{
Guichardant M, Véricel E, Lagarde $\mathrm{M}^{*}$ \\ Univ-Lyon, Inserm UMR 1060 \& Inra UMR 1397 (CarMeN Laboratory), IMBL, INSA-Lyon, \\ Villeurbanne, France \\ *: corresponding author (michel.lagarde@ insa-lyon.fr).
}

\section{Highlights:}

The $E, Z, E$ conjugated triene of double LOX products is crucial for platelet inhibition R/S di-hydroxylated stereoisomers tend to be more active than the S/S ones

Altered GPx activity may favor epoxide intermediate from the first lipoxygenation

\begin{abstract}
The double lipoxygenation of polyunsaturated fatty acids (PUFA) is possible with PUFA having at least three methylene-interrupted double bonds. Several PUFA of the omega-3/n-3 and -6 families may be converted through this route, and the products show interesting inhibitory effects on blood platelet function and cyclooxygenase activities. This review focuses on two main omega-3 PUFA of nutritional interest, namely docosahexaenoic acid (DHA/22:6n-3) and alpha linolenic acid (ALA/18:3n-3). The chemical configuration of the double lipoxygenase end-product from DHA (protectin DX) is compared with that of protectin D1 which is produced through a mono-lipoxygenation step followed by an epoxidation and epoxide hydrolysis process. The different metabolic pathways are discussed as well as the different biological activities of both protectins.
\end{abstract}

Keywords: Omega-3 fatty acids; Protectins; Linotrins; Stereochemistry; Platelet aggregation.

\section{Introduction}

Lipoxygenases are enzymes, first described in plants [1], which catalyze the di-oxygenation of polyunsaturated fatty acids (PUFA) having at least one cis,cis/Z,Z-1,4-pentadiene motif in their structures. In animals, the first fatty acid hydroperoxide product of this dioxygenation is quickly reduced into the corresponding hydroxide by glutathione peroxidases, mainly the cytosolic isoform (GPx-1) [2]. The resulting product is an alpha-hydroxy-trans,cis (1-OH$2 E, 4 Z$ ) conjugated diene derivative, with most frequently an $\mathrm{S}$ configuration for the oxygenated carbon. To undergo a double lipoxygenation, PUFA must have at least three methylene interrupted double bonds. After reduction by GPx, the double hydroxylated motif is 1-(S)-OH-2E,4Z,6E-8-(S)-OH, first-called "poxytrin" [3]. However, many other di- and trihydroxylated derivatives may be produced from PUFA with the involvement of at least one lipoxygenase. This is the case with protectin D1 and maresin-1 from docosahexaenoic acid, for which the first hydroperoxides produced by lipoxygenases are transformed into an epoxide. Then, an epoxide hydrolase opens the epoxide into a hydroxide, and hydroxylate the chain to make a similar motif as for poxytrins, but with a different geometry of the conjugated 
triene and different stereochemistry. Compared to poxytrin (1(S)-OH-2 $\underline{\boldsymbol{E}}, \mathbf{4} \underline{\boldsymbol{Z}}, 6 \underline{\boldsymbol{E}}-8(\underline{\mathbf{S}})-\mathrm{OH})$, protectin D1 and maresin-1 are single lipoxygenase products with the common motif $10(\underline{\mathbf{R}})$ $\mathrm{OH}-11 \underline{\boldsymbol{E}}, 13 \underline{\boldsymbol{E}}, 15 \underline{\boldsymbol{Z}}-17 \mathrm{~S}-\mathrm{OH}-22: 6$ and $7(\underline{\mathbf{R}})-\mathrm{OH}-8 \underline{\boldsymbol{E}}, 10 \underline{\boldsymbol{E}}, 12 \underline{\boldsymbol{Z}}-14(\mathrm{~S})-\mathrm{OH}-22: 6$, respectively [4],[5],[6]. The differences between both motifs (R/S \& E,Z,E / E,E,Z) appear underlined in bold. This review will only focus on double lipoxygenase products and their biological functions.

\section{Double lipoxygenation of arachidonic acid and other omega-6 PUFA}

Arachidonic acid (ArA/20:4n-6) has been the first described PUFA to be doubly lipoxygenated, leading to an isomer of leukotriene $\mathrm{B}_{4} \quad(5(\mathrm{~S}), 12(\underline{\mathbf{R}})$-diOH-eicosa$6 \underline{\boldsymbol{Z}}, 8 \underline{\boldsymbol{E}}, 10 \underline{\underline{E}}, 14 Z$-tetraenoic acid), the 5-lipoxygenase product made in neutrophils, which has a high chemotactic activity. The 12-lipoxygenation responsible to make the $\mathrm{LTB}_{4}$ isomer occurs in platelets from 5-HETE (5(S)-OH-eicosa-6E,8Z,11Z,14Z-tetraenoic acid) exported from neutrophils [7]. This isomer of $\mathrm{LTB}_{4}$ then produced by double lipoxygenation is $5(\mathrm{~S}), 12(\underline{\mathbf{S}})$ diOH-eicosa- $6 \underline{\boldsymbol{E}}, 8 \underline{\boldsymbol{Z}}, 10 \underline{\boldsymbol{E}}, 14 Z$-tetraenoic acid or 5(S),12(S)-diHETE. Because of its conjugated triene motif, 5(S),12(S)-diHETE belongs to the later reported poxytrin family. Contrary to $\mathrm{LTB}_{4}$, which is the reference leukotriene to be active on neutrophil chemotaxis, $5(\mathrm{~S}), 12(\mathrm{~S})$ diHETE appears quasi inactive on this function [8]. At the opposite, 5(S),12(S)-diHETE inhibits thromboxane-induced platelet aggregation, whereas $\mathrm{LTB}_{4}$ is totally inactive on that action [9]. This indicates a crucial relevance of the conjugated motif of di-OH-PUFA for their biological function. The E,Z,E conjugated triene has also been described after double lipoxygenation of ArA by 15-LOX [10]. This double lipoxygenase end-product of ArA, 8(S),15(S)-eicosa-5Z,9 $\underline{\boldsymbol{E}}, 11 \underline{\boldsymbol{Z}}, 13 \underline{\boldsymbol{E}}$-tetraenoic acid shares the chemotactic activity of $\mathrm{LTB}_{4}$, being however three-times less potent [11].

For the other omega-6 PUFA of biological interest, having at least three methylene interrupted double bonds, namely gamma-linolenic (GLA), dihomo-gamma-linolenic (DGLA), adrenic (AdA) and n-6 docosapentaenoic (DPAn-6) acids, no specific report has been made on their double lipoxygenase products. However, these PUFA are a priori potential substrates for a possible double lipoxygenation.

\section{Double lipoxygenation of docosahexaenoic and alpha-linolenic acids}

Because of its crucial role in the brain development and function, as well as its relevance following marine lipid diet, docosahexaenoic acid (DHA/22:6n-3) has been early studied for its conversion into oxygenated products. Its mono-oxygenation by classical lipoxygenases leads to mainly five end-products, namely 4- and 7-hydroxy-docosahexaenoic acid (4- and 7HDoHE) through 5-LOX, 11- and 14-HDoHE through 12-LOX [12], and 17-HDoHE through 15-LOX. The latter may additionally oxygenate carbon 10, then making a conjugated triene between carbons 10 and 17, with the same mechanism as described for ArA to produce 8(S),15(S)-diOH-eicosa-5Z,9E,11Z,13E-tetraenoic acid [10]. The double lipoxygenase product from DHA is $10(\mathrm{~S}), 17(\mathrm{~S})$-diOH-docosa-4Z,7Z,11E,13Z,15E-hexaenoic acid [13]. This double lipoxygenase product has been named protectin DX (PDX) to differentiate it from protectin D1 or neuroprotectin D1 (10(R),17(S)-diOH-docosa-4Z,7Z,11E,13E,15Z-hexaenoic acid), which is a potent anti-inflammatory derivative (reviewed by Serhan \& Chiang [14] \& Serhan et al [5]). In contrast to PD1, PDX is virtually not active in inflammation [14] but appears to be a potent inhibitor of platelet activation, especially against $\mathrm{TxA}_{2}$-induced aggregation [13] \& [3]. However, PD1 is not active against platelet aggregation [15]. As 
several other di-OH-PUFA with the E,Z,E conjugated triene, including the $\mathrm{LTB}_{4}$ isomer (see above), share these platelet inhibition effects, they have been tentatively called "poxytrins" for PUFA oxygenated trienes [3] \&[16]. Moreover, all the other di-hydroxylated PUFA tested that do not exhibit the $E, Z, E$ conjugated triene were inactive on platelets.

Since these early descriptions, PDX has been reported as an active metabolite in several biological systems, such as (i) the inhibition of reactive oxygen species production by activated neutrophils [17], (ii) the inhibition of the insulin resistance in skeletal muscles of obese mice [18], (iii) the inhibition of neutrophil extravasation [19], and (iv) the inhibition of the lipopolysaccharide-induced inflammation ([20] \& [21]. Even, the inhibition of the influenza virus replication attributed first to PD1 [22], was indeed due to PDX [23] \& [24]. In most systems showing a biological effects of PDX, the endogenous production of it could be observed, whereas PD1 was hardly found [19], [25], [26]. In normal rat brains, we were able to measure PDX but not PD1 [27], although small amounts of PD1 could be detected in brains submitted to inflammatory stimuli (unpublished results). This suggests that the double lipoxygenase end-product of DHA, PDX, is a possible endogenous mediator, presumably because of an active glutathione peroxidase 1 (GPx-1) which efficiently reduces the first oxygenated product 17-OOH-22:6 into 17-OH-22:6, the latter being a substrate for the second lipoxygenation at carbon 10. Then, the end-product 10,17-diOH-22:6 (PDX) subsequently follows due to GPx-1 action. In case of altered GPx-1 activity, e.g. in oxidative stress states such as inflammation, it is possible that part of 17-OOH-22:6 may escape its reduction into 17-OH-22:6, allowing the 16,17-epoxy derivative formation. Then an epoxide hydrolase may act to produce $10(\mathrm{R}), 17(\mathrm{~S})$-diOH-4Z,7Z,11E,13E,15Z-22:6 (reviewed by Serhan et al [5]). This is different from $\mathrm{LTB}_{4}$ production from ArA with the unique dual activity of 5-LOX that converts ArA into 5-HpETE, and further to the epoxide LTA 4 through an "epoxide synthase" activity [28]. LTA 4 is further converted into $\mathrm{LTB}_{4}$ by the epoxide hydrolase $\mathrm{LTB}_{4}$ synthase [29]. 15-LOX being devoid of "epoxide synthase" activity, 17-OOH-22:6 should be quickly reduced into $17-\mathrm{OH}-22: 6$, unless GPx-1 is altered. We might then speculate that PD1 production might be a quite relevant pathophysiological response to altered GPx-1. Figure 1 summarizes the two different pathways leading to protectins D1 and DX.

The double lipoxygenation of other omega-3/n-3 PUFA such as alpha-linolenic acid (ALA/18:3n-3) and its intermediates to DHA, namely eicosapentaenoic (EPA/20:5n-3) and docosapentaenoic (DPA/22:5n-3) acids is also possible. Accounting for the relatively high abundance of ALA in human diets, with 1-2 g for daily intake recommendation, we have investigated its metabolism by soybean lipoxygenase (15-LOX). Surprisingly, we found four different dioxygenation end-products, all 9,16-di-OH derivatives. Two major ones contained the $E, Z, E$ conjugated triene reported for poxytrins, whereas two others, produced in smaller quantities (around 2-times less), contained the all-trans conjugated triene $E, E, E$, and each group of two where stereoisomers ( $\mathrm{R}$ or $\mathrm{S}$ ) at carbon 9. Interestingly, only the two $E, Z, E$ isomers are active to inhibit blood platelet aggregation and purified cyclooxygenase- 1 and -2 , with the 9R stereoisomer being the most potent [30], and later called linotrins [16]. The relative higher biological activity of $\mathrm{R}$ stereoisomers compared to $\mathrm{S}$ ones recalls that such an observation had already been done for the inhibition of platelet aggregation by the $17 \mathrm{R}$ isomer of PDX [3], and several R mono-hydroxylated derivatives, compared to their S stereoisomers [31]. This is in agreement with the finding that the 17R isomer of PD1, produced by aspirin treated cells in which COX-2 still makes 17(R)-OOH-22:6, further converted into $10(\mathrm{R}), 17(\mathrm{R})$-diOH-4Z,7Z,11E,13E,15Z-22:6 and called AT-PD1 for aspirin-treated [32], is at least as potent as PD1 [33]. 


\section{Conclusions}

Overall, this short review points out the importance of conjugated triene isomers for specific biological activities. The double lipoxygenase end-products with the $E, Z, E$ conjugated triene motif exert potent inhibition of blood platelet function and of cyclooxygenase activities (summarized in Figure 2). On the other hand, mono lipoxygenation followed by epoxide formation from the hydroperoxide intermediate, and the final production of di-hydroxylated isomers with the Z,E,E motif, leads to inhibitors of inflammation which are virtually inactive on platelets. This has been especially shown with DHA as a substrate.

\section{Acknowledgements}

The authors want to thank Inserm, Inra and the Ministry of Research through INSA-Lyon for their continuous support. Part of the original work supporting this review has been done by Drs Ping Chen and Miao Liu during their $\mathrm{PhD}$ thesis in our laboratory.

\section{References}

[1] G.A. Veldink, J.F.G. Vliegenthart, J. Boldingh, Plant lipoxygenases, Progress in the Chemistry of Fats and Other Lipids. 15 (1977) 131-166. doi:10.1016/00796832(77)90014-3.

[2] R.W. Bryant, J.M. Bailey, Role of selenium-dependent glutathione peroxidase in platelet lipoxygenase metabolism, Prog. Lipid Res. 20 (1981) 189-194.

[3] P. Chen, E. Véricel, M. Lagarde, M. Guichardant, Poxytrins, a class of oxygenated products from polyunsaturated fatty acids, potently inhibit blood platelet aggregation, FASEB J. 25 (2011) 382-388. doi:10.1096/fj.10-161836.

[4] C.N. Serhan, R. Yang, K. Martinod, K. Kasuga, P.S. Pillai, T.F. Porter, S.F. Oh, M. Spite, Maresins: novel macrophage mediators with potent antiinflammatory and proresolving actions, J. Exp. Med. 206 (2009) 15-23. doi:10.1084/jem.20081880.

[5] C.N. Serhan, J. Dalli, R.A. Colas, J.W. Winkler, N. Chiang, Protectins and maresins: New pro-resolving families of mediators in acute inflammation and resolution bioactive metabolome, Biochim. Biophys. Acta. 1851 (2015) 397-413. doi:10.1016/j.bbalip.2014.08.006.

[6] M. Lagarde, C. Calzada, C. Jouvène, N. Bernoud-Hubac, M. Létisse, M. Guichardant, E. Véricel, Functional fluxolipidomics of polyunsaturated fatty acids and oxygenated metabolites in the blood vessel compartment, Prog. Lipid Res. 60 (2015) 41-49. doi:10.1016/j.plipres.2015.10.001.

[7] P. Borgeat, B. Fruteau de Laclos, S. Picard, J. Drapeau, P. Vallerand, E.J. Corey, Studies on the mechanism of formation of the 5S, 12S-dihydroxy-6,8,10,14(E,Z,E,Z)icosatetraenoic acid in leukocytes, Prostaglandins. 23 (1982) 713-724.

[8] C.A. Dahinden, R.M. Clancy, T.E. Hugli, Stereospecificity of leukotriene B4 and structure-function relationships for chemotaxis of human neutrophils, J. Immunol. 133 (1984) 1477-1482.

[9] M. Croset, M. Lagarde, Stereospecific inhibition of PGH2-induced platelet aggregation by lipoxygenase products of icosaenoic acids, Biochem. Biophys. Res. Commun. 112 (1983) 878-883. 
[10] R.L. Maas, A.R. Brash, J.A. Oates, A second pathway of leukotriene biosynthesis in porcine leukocytes, Proc. Natl. Acad. Sci. U.S.A. 78 (1981) 5523-5527.

[11] R. Sehmi, O. Cromwell, G.W. Taylor, A.B. Kay, Identification of guinea pig eosinophil chemotactic factor of anaphylaxis as leukotriene B4 and 8(S),15(S)-dihydroxy5,9,11,13(Z,E,Z,E)-eicosatetraenoic acid, J. Immunol. 147 (1991) 2276-2283.

[12] M.I. Aveldaño, H. Sprecher, Synthesis of hydroxy fatty acids from 4, 7, 10, 13, 16, 19[1-14C] docosahexaenoic acid by human platelets, J. Biol. Chem. 258 (1983) 9339-9343.

[13] P. Chen, B. Fenet, S. Michaud, N. Tomczyk, E. Véricel, M. Lagarde, M. Guichardant, Full characterization of PDX, a neuroprotectin/protectin D1 isomer, which inhibits blood platelet aggregation, FEBS Lett. 583 (2009) 3478-3484. doi:10.1016/j.febslet.2009.10.004.

[14] C.N. Serhan, N. Chiang, Endogenous pro-resolving and anti-inflammatory lipid mediators: a new pharmacologic genus, Br. J. Pharmacol. 153 Suppl 1 (2008) S200-215. doi:10.1038/sj.bjp.0707489.

[15] M. Dona, G. Fredman, J.M. Schwab, N. Chiang, M. Arita, A. Goodarzi, G. Cheng, U.H. von Andrian, C.N. Serhan, Resolvin E1, an EPA-derived mediator in whole blood, selectively counterregulates leukocytes and platelets, Blood. 112 (2008) 848-855. doi:10.1182/blood-2007-11-122598.

[16] M. Lagarde, E. Véricel, M. Liu, P. Chen, M. Guichardant, Structure-function relationships of non-cyclic dioxygenase products from polyunsaturated fatty acids: poxytrins as a class of bioactive derivatives, Biochimie. 107 Pt A (2014) 91-94. doi:10.1016/j.biochi.2014.09.008.

[17] M. Liu, T. Boussetta, K. Makni-Maalej, M. Fay, F. Driss, J. El-Benna, M. Lagarde, M. Guichardant, Protectin DX, a double lipoxygenase product of DHA, inhibits both ROS production in human neutrophils and cyclooxygenase activities, Lipids. 49 (2014) 49-57. doi:10.1007/s11745-013-3863-6.

[18] P.J. White, P. St-Pierre, A. Charbonneau, P.L. Mitchell, E. St-Amand, B. Marcotte, A. Marette, Protectin DX alleviates insulin resistance by activating a myokine-liver glucoregulatory axis, Nat. Med. 20 (2014) 664-669. doi:10.1038/nm.3549.

[19] K. Stein, M. Stoffels, M. Lysson, B. Schneiker, O. Dewald, G. Krönke, J.C. Kalff, S. Wehner, A role for 12/15-lipoxygenase-derived proresolving mediators in postoperative ileus: protectin DX-regulated neutrophil extravasation, J. Leukoc. Biol. 99 (2016) 231239. doi:10.1189/jlb.3HI0515-189R.

[20] T.W. Jung, Y.H. Chung, H.-C. Kim, A.M. Abd El-Aty, J.H. Jeong, Protectin DX attenuates LPS-induced inflammation and insulin resistance in adipocytes via AMPKmediated suppression of the NFkB pathway, Am. J. Physiol. Endocrinol. Metab. (2018). doi:10.1152/ajpendo.00408.2017.

[21] X.-J. Zhuo, Y. Hao, F. Cao, S.-F. Yan, H. Li, Q. Wang, B.-H. Cheng, B.-Y. Ying, F.G. Smith, S.-W. Jin, Protectin DX increases alveolar fluid clearance in rats with lipopolysaccharide-induced acute lung injury, Exp. Mol. Med. 50 (2018) 49. doi:10.1038/s12276-018-0075-4.

[22] M. Morita, K. Kuba, A. Ichikawa, M. Nakayama, J. Katahira, R. Iwamoto, T. Watanebe, S. Sakabe, T. Daidoji, S. Nakamura, A. Kadowaki, T. Ohto, H. Nakanishi, R. Taguchi, T. Nakaya, M. Murakami, Y. Yoneda, H. Arai, Y. Kawaoka, J.M. Penninger, M. Arita, Y. Imai, The lipid mediator protectin D1 inhibits influenza virus replication and improves severe influenza, Cell. 153 (2013) 112-125. doi:10.1016/j.cell.2013.02.027.

[23] L. Balas, M. Guichardant, T. Durand, M. Lagarde, Confusion between protectin D1 (PD1) and its isomer protectin DX (PDX). An overview on the dihydroxy-docosatrienes described to date, Biochimie. 99 (2014) 1-7. doi:10.1016/j.biochi.2013.11.006. 
[24] Y. Imai, Role of omega-3 PUFA-derived mediators, the protectins, in influenza virus infection, Biochim. Biophys. Acta. 1851 (2015) 496-502.

doi:10.1016/j.bbalip.2015.01.006.

[25] P.L. Mitchell, R. Nachbar, D. Lachance, P. St-Pierre, J. Trottier, O. Barbier, A. Marette, Treatment with a novel agent combining docosahexaenoate and metformin increases protectin DX and IL-6 production in skeletal muscle and reduces insulin resistance in obese diabetic db/db mice, Diabetes Obes Metab. 19 (2017) 313-319. doi:10.1111/dom.12818.

[26] R. Kosaraju, W. Guesdon, M.J. Crouch, H.L. Teague, E.M. Sullivan, E.A. Karlsson, S. Schultz-Cherry, K. Gowdy, L.C. Bridges, L.R. Reese, P.D. Neufer, M. Armstrong, N. Reisdorph, J.J. Milner, M. Beck, S.R. Shaikh, B Cell Activity Is Impaired in Human and Mouse Obesity and Is Responsive to an Essential Fatty Acid upon Murine Influenza Infection, J. Immunol. 198 (2017) 4738-4752. doi:10.4049/jimmunol.1601031.

[27] C. Jouvène, B. Fourmaux, A. Géloën, L. Balas, T. Durand, M. Lagarde, M. Létisse, M. Guichardant, Ultra-Performance Liquid Chromatography-Mass Spectrometry Analysis of Free and Esterified Oxygenated Derivatives from Docosahexaenoic Acid in Rat Brain, Lipids. 53 (2018) 103-116. doi:10.1002/lipd.12006.

[28] T. Shimizu, O. Rådmark, B. Samuelsson, Enzyme with dual lipoxygenase activities catalyzes leukotriene A4 synthesis from arachidonic acid, Proc. Natl. Acad. Sci. U.S.A. 81 (1984) 689-693.

[29] B. Samuelsson, C.D. Funk, Enzymes involved in the biosynthesis of leukotriene B4, J. Biol. Chem. 264 (1989) 19469-19472.

[30] M. Liu, P. Chen, E. Véricel, M. Lelli, L. Béguin, M. Lagarde, M. Guichardant, Characterization and biological effects of di-hydroxylated compounds deriving from the lipoxygenation of ALA, J. Lipid Res. 54 (2013) 2083-2094. doi:10.1194/jlr.M035139.

[31] M. Lagarde, M.M. Boutillon, M. Guichardant, J.P. Lellouche, J.P. Beaucourt, A. Vanhove, R. Grée, Further studies on the anti-thromboxane A2 activity of monohydroxylated fatty acids, Biochem. Pharmacol. 38 (1989) 1863-1864.

[32] C.N. Serhan, G. Fredman, R. Yang, S. Karamnov, L.S. Belayev, N.G. Bazan, M. Zhu, J.W. Winkler, N.A. Petasis, Novel proresolving aspirin-triggered DHA pathway, Chem. Biol. 18 (2011) 976-987. doi:10.1016/j.chembiol.2011.06.008.

[33] M. Shinohara, V. Mirakaj, C.N. Serhan, Functional Metabolomics Reveals Novel Active Products in the DHA Metabolome, Front Immunol. 3 (2012) 81. doi:10.3389/fimmu.2012.00081.

\section{Figure legends}

Figure 1. This represents a scheme for protectins D1 and DX formation. This shows the initial common step for 15-LOX to produce 17-OOH-22:6. Then, the cytosolic glutathione peroxidase (GPx-1) immediately reduces 17-OOH-22:6 into 17-OH-22:6, which undergoes a second lipoxygenation at carbon 10, with the 10-hydroperoxide that is also reduced, to finally produce PDX. Due to this double lipoxygenation, the stereochemistry of both alcohols is $S$, and the geometry of the conjugated triene is $E, Z, E$, reflecting the double $E, Z$ conjugation. In case of deficient GPx-1, some rearrangement of 17-OOH-22:6 in the corresponding 16,17epoxy-22:6 occurs, allowing an epoxide hydrolase to act upon, producing PD1/NPD1 with the $10 \mathrm{R}, 17 \mathrm{~S}$ stereochemistry and an $E, E, Z$ conjugated triene, as observed after LTA 4 hydrolase / 
$\mathrm{LTB}_{4}$ synthase action on $\mathrm{LTA}_{4}$ from arachidonic acid (see text). In each product, the geometry of conjugated diene and trienes is underlined.

Figure 2. The main biological effects of poxytrins, e.g. PDX from DHA/22:6n-3 and linotrins from ALA/18:3n-3 are schematized. When blood platelets are activated by collagen, their aggregation is mediated by $\mathrm{PGH}_{2}$-derived $\mathrm{TxA}_{2}$ produced by cyclooxygenase-1 (COX-1) / Thromboxane (Tx) synthase from endogenous arachidonic acid (ArA). PDX or linotrins may then inhibit COX-1 and antagonize $\mathrm{TxA}_{2}$ action. 


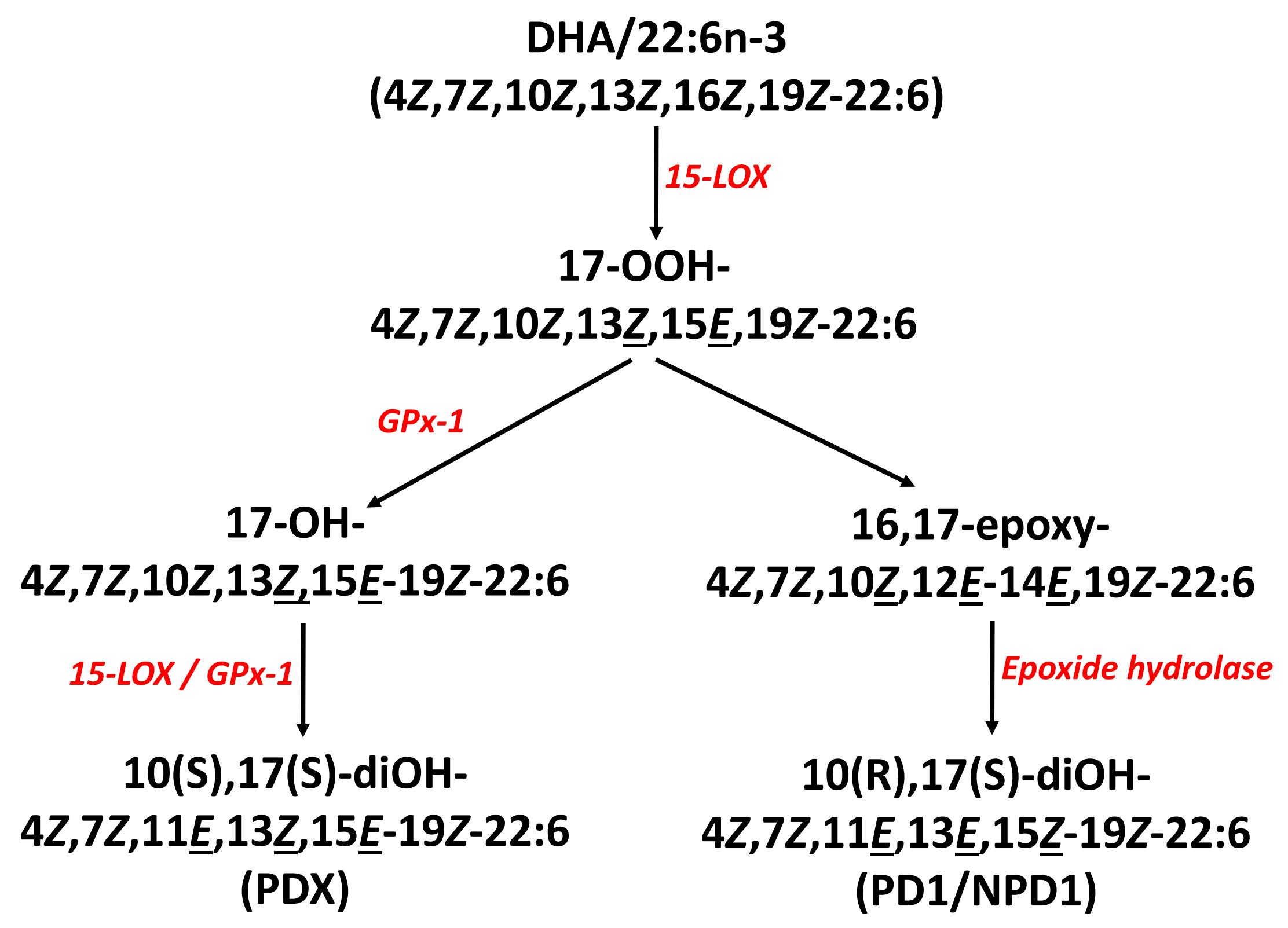




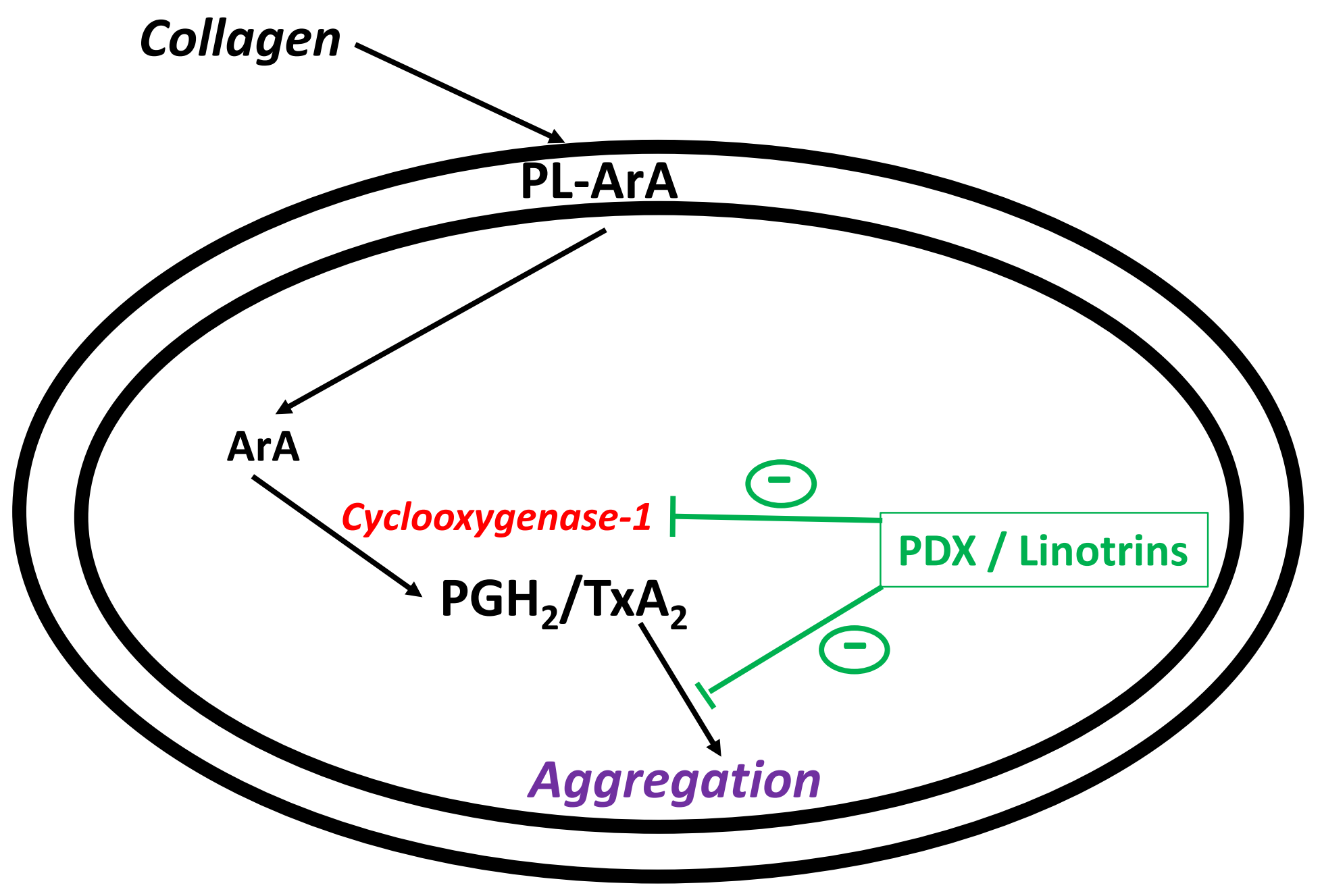

